\title{
NADZIEJA NA JEDNOŚĆ? HEREZJE I HERETYCY W LISTACH ŚW. AMBROŻEGO**
}

Św. Ambroży z Mediolanu znany jest ze swej nieugiętej postawy wobec herezji i heretyków. Jako biskupowi i pasterzowi Kościoła w Mediolanie przyszło mu wielokrotnie zajmować wobec nich stanowisko. Został wszak biskupem cesarskiej stolicy jako następca ariańskiego biskupa Auksencjusza ${ }^{1}$, a w trakcie swego episkopatu musiał się zmierzyć z cesarzową Justyną, zwolenniczką arianizmu, co skutkowało na przykład najsłynniejszym konfliktem okresu jego biskupstwa - tzw. sporem o bazyliki, w którym przeciwstawił się cesarzowi w przekazaniu arianom jednego z mediolańskich kościołó ${ }^{2}$. Z perspektywy historyczno-teologicznej oczywiście istotne w polemice $\mathrm{z}$ herezjami są traktaty antyheretyckie, bądź też pozytywne przedstawienie ortodoksyjnej doktryny w traktatach i dziełach egzegetycznych ${ }^{3}$, jednak niezwykle ważnym źródłem wydaje się również korespondencja biskupa Ambrożego. W niej przecież w zupełnie inny sposób - często pozbawiony naukowości i oficjalności - omawiał te same problemy, które były przedmiotem uczonych traktatów. W jaki więc sposób w swoich listach biskup Ambroży przedstawiał herezje

* Ks. dr hab. Marcin Wysocki - adiunkt w Katedrze Patrologii Greckiej i Łacińskiej w Instytucie Historii Kościoła i Patrologii na Wydziale Teologii Katolickiego Uniwersytetu Lubelskiego Jana Pawła II; e-mail: mwysocki@kul.lublin.pl.

${ }^{* *}$ Praca powstała w wyniku realizacji projektu badawczego o $\mathrm{nr}$ 2014/15/B/HS1/03851, finansowanego ze środków Narodowego Centrum Nauki.

${ }^{1}$ Por. M. Simonetti, Aussenzio di Milano, DPAC I 449-450; J. Grzywaczewski, Appointing Bishops in the First Centuries, Lublin 2013, 75-77; Y.M. Duval, Ambroise, de son élection à sa consécration, w: Ambrosius Episcopus. Atti del Congresso internazionale di studi ambrosiani nel XVI centenario della elevazione di sant'Ambrogio alla cattedra episcopale, ed. G. Lazzati, Studia Patristica Mediolanensia 6, Milano 1976, 243-283.

${ }^{2} \mathrm{Na}$ temat sporu o bazyliki zob. L. Cracco Ruggini, Ambrogio a le opposizioni anticattoliche fra il 383 e il 390, „Augustinianum” 14 (1974) 409-449; G. Nauroy, Le fouet et le miel. Le combat d'Ambroise en 386 contre l'arianisme milanaise, RechAug 23 (1988) 3-86; T.D. Barnes, Ambrose and the Basilicas of Milan in 385 and 386: The primary documents and their implications, ZACh 4 (2000) 282-299; M. Colish, Why the Portiana?: Reflections on the Milanese Basilica Crisis of 386, JECS 10 (2002) 361-372.

${ }^{3}$ Należy tu przede wszystkim zwrócić uwagę na dzieło św. Ambrożego De fide skierowane do cesarza Gracjana. 
i heretyków, w jaki sposób ich opisywał i jakie argumenty przeciwko nim w swej epistolografii wysuwał? A może widział w nich nadzieję na powrót heretyków do wspólnoty Kościoła katolickiego i jedność wiary?

Patrząc całościowo na epistolografię Ambrożego można odnieść wrażenie, że biskup Mediolanu nie miał właściwie problemów z heretykami i nie było potrzeby poświęcać im miejsca i czasu w korespondencji. Bo rzeczywiście generalnie w swoich listach jest bardzo powściagliwy, jeżeli chodzi o herezje i heretyków. Bardziej interesują go kwestie pastoralne, egzegetyczne czy polityczne. Nawet relacjonując spór o bazyliki w liście do swej siostry Marceliny więcej uwagi poświęca cesarzowi niż arianom ${ }^{4}$. A jednak wczytawszy się głębiej w listy Ambrożego dostrzeżemy szereg nawiązań do herezji, które nie są przede wszystkim odniesieniami dogmatycznymi, ale wpisują się właśnie w pastoralny profil działalności biskupa Mediolanu i leżącą mu szczególnie na sercu jedność wspólnoty eklezjalnej ${ }^{5}$.

1. Określenie i istota herezji i heretyków. W swoich listach św. Ambroży odnosi się przede wszystkim do dwóch herezji: arianizmu i manicheizmu. Na ich bazie ukazuje, czym jest herezja. Biskup zdecydowanie podkreśla, że herezja „zaprzecza prawdzie" (abnegat veritatem ${ }^{6}$; jest trucizną ${ }^{7} \mathrm{i}$,wielkim szaleństwem" (quanta amentia) ${ }^{8}$; cechuje ją bezbożność ${ }^{9}$; jest wiarołomstwem ${ }^{10}$, zakłóceniem pokoju Kościoła ${ }^{11}$; ten, kto trwa w herezji jest „umarły i pogrzebany" ${ }^{12}$; umysły heretyków są nasycone jadem niewiary ${ }^{13}$. Heretycy są wilkami, które próbują wkraść się do owczarni Chrystusa ${ }^{14}$.

Szczególnie mocno brzmią słowa Ambrożego porównujące herezje i heretyków z diabłem. Co ciekawe, według biskupa Mediolanu, heretycy (w tym przypadku arianie) są gorsi od diabła. Wobec odnalezienia relikwii męczenników Protazego i Gerwazego oraz cudów i nawróceń z tym wydarzeniem związanych, Ambroży potępia niewiarę i postępowanie heretyków, wskazując, ze diabeł uznaje te dzieła, a heretycy nie. W liście 77. tak pisze:

\footnotetext{
${ }^{4}$ Por. Ambrosius, Epistula 76.

${ }^{5}$ Por. J. Pałucki, Święty Ambroży jako duszpasterz w świetle ekshortacji pastoralnych, Lublin 1996; tenże, Św. Ambroży, opatrznościowy maż Kościola - między starymi a nowymi czasy, w: Bóg Ojciec i przełom wieków w myśli patrystycznej, red. I. Salamonowicz-Górska - J. Naumowicz - S. Strękowski, Warszawa 2001 = SACh 15 (2001) 196-207.

${ }^{6}$ Ambrosius, Epistula 15*, 13, SAEMO 21, ed. G. Banterle, Milano - Roma 1988, 332, thum. P. Nowak: Ambroży z Mediolanu, Listy, t. 3, BOK 28, Kraków 2012, 255.

${ }^{7}$ Por. tamże 39, 1 .

${ }^{8}$ Tamże 15*, 4, SAEMO 21, 328, BOK 28, 252.

${ }^{9}$ Por. tamże $15^{*}, 13$.

${ }^{10}$ Por. tamże $15^{*}, 12$

${ }^{11}$ Por. tamże $5^{*}, 3$.

${ }^{12}$ Tamże 77, 21, SAEMO 21,166: „illum mortuum, illum funereum”, BOK 28, 116.

${ }^{13}$ Por. tamże 36, 28.

${ }^{14}$ Por. tamże $15^{*}, 1$.
} 
„Słyszeliśmy dzisiaj, jak mówili ci, na których była nakładana ręka, że nikt nie może być zbawiony, jak tylko ten, kto wierzy w Ojca i Syna, i Ducha Świętego, i że jest umarły i pogrzebany ten, kto neguje Ducha Świętego, kto nie wierzy we wszechmoc Trójcy. Diabeł to wyznaje, lecz arianie nie chca wyznać. Diabeł mówi: «Niech będzie dręczony tak, jak on był dręczony przez męczenników, ponieważ neguje bóstwo Ducha Świętego». Nie przyjmuję od diabła świadectwa, lecz wyznanie - tak. Diabeł powiedział to niechętnie, zmuszony i dręczony. To, co nieprawość ukrywa, wymusza przemoc. Diabeł ustępuje przed razami, arianie jeszcze nie potrafią ustapić. lleż już wycierpieli i - jak faraon (por. Wj 7-11) - uparcie trwają w swych błędach! Diabeł mówił, jak czytamy w Piśmie: Wiem, kto jesteś: Ty jesteś Synem Boga żywego (por. Mk 1, 24; Mt 16, 16); Żydzi mówili: Nie wiemy, kim On jest (por. J 9, 29). Dzisiaj i poprzedniego dnia i nocy mówiły demony: «Wiemy, że jesteście męczennikami», zaś Arianie mówią: «Nie wiemy, nie chcemy poznać [prawdy], nie chcemy uwierzyć». Mówią demony do męczenników: «Przyszliście nas zgubić»; arianie mówią: «Te udręki demonów nie są prawdziwe, lecz [są to] udawane i wymyślone sztuczki». Słyszałem o wielu rzeczach wymyślonych, ale nikt nigdy nie potrafił udawać do tego stopnia, by upodobnił się do demona"15.

Diabeł - przymuszony wprawdzie - przyjmuje prawdę o Bogu i dzieła męczenników, arianie zaś nie.

Równie ostrym zestawieniem jest w listach Ambrożego porównanie heretyków do Żydów, co w kontekście listów biskupa dotyczących wydarzeń w Callinicum ${ }^{16}$, gdzie podpalono synagogę, jest szczególnie wyraziste. Arianie są najpierw zrównani z Żydami przez to, że i jednych i drugich raduje

${ }^{15}$ Tamże 77, 21-22, SAEMO 21, 166: „Audiuimus hodie dicentes eos quibus minus imponebatur neminem posse esse saluum nisi qui in patrem et filium et spiritum sanctum credidisset, illum mortuum illum funereum qui spiritum sanctum negaret, qui trinitatis omnipotentem uirtutem non crederet. Confitetur hoc diabolus, sed Ariani nolunt fateri. Dicit diabolus: «Sic torqueatur quemadmodum ipse a martyribus torquebatur qui spiritus sanctem deitatem negaret». Non accipio a diabolo testimonium sed confessionem. Inuitus dixit diabolus sed exactus et tortus. Quod nequitia supprimit extorquet iniuria. Cedit diabolus plagis et adhuc cedere nesciunt Arriani. Quanta perpessi sunt et, quemadmodum Pharao, malis suis indurantur! Dicebat diabolus ut scriptum legimus: «Scio te quis sis, tu es filius dei uiui», dicebant Iudaei: «Nescimus, nolumus intellegere, nolumus credere». Dicunt daemones martyribus: «Venistis perdere nos», Ariani dicunt: «Non sunt daemonum uera tormenta sed ficta et composita ludibria». Audiui multa componi, hoc nemo umquam fingere potuit ut daemonium se esse simularet", BOK 28, 116-117.

${ }^{16}$ Por. tamże 74; 1a*. Zob. F. Barth, Ambrosius und die Synagoge von Callinicum, ,Theologische Zeitschrift aus der Schweiz" b.d. (1889) 65-86; P. de Labriolle, Saint Ambroise et l'affaire de Callinicum, „Revue des Cours et Conférences” 16 (1898) 78-96; G. Nauroy, Ambroise et la question juive à Milan à la fin du IV siècle. Une nouvelle lecture de l'Epistula 74 (Maur. 40) à Théodose, w: Les chrétiens et leurs adversaires dans l'Occident latin au IV siècle, ed. J.-M. Poinsotte, Rouen 2001, 37-59. 
słuchanie o znieważaniu Chrystusa i zaprzeczanie Jego bóstwa ${ }^{17}$. Niewiare w zrodzenie Jezusa z Dziewicy określa Ambroży jako „szaleństwo prawie równe szaleństwu nowych Żydów"18. Później jednak Biskup zmienia nastawienie i ostrzej traktuje arian określając ich jako gorszych od Żydów, gdyż chcą dać cesarzowi prawa należące do Kościoła i są wiarołomcami ${ }^{19}$.

Ambroży opisuje w listach także niegodne postępowanie heretyków wobec Kościoła i wiernych, które oczywiście zdecydowanie potępia. W sposób szczególny podkreśla biskup Mediolanu wyśmiewanie przez heretyków postaw wiernych ortodoksyjnych. Wskazuje na uwielbianie Chrystusa, na przykład przez dzieci, co wyśmiewają i czego nie mogą znieść heretycy ${ }^{20}$. Na przykładzie ariańskiego biskupa Merkuryna/Auksencjusza Ambroży ukazuje zakłamanie i zmienność heretyków. Przedstawia go jako człowieka, który zmienił swoje imię (z Merkuryn na Auksencjusz), aby nikt go nie rozpoznał, „W celu oszukania ludu”21. To jednak nie sprawiło - co podkreśla biskup Mediolanu - że zmienił on swe wiarołomstwo. Jedynie zdjął skórę wilka, lecz wkrótce przywdział ją na nowo - jak obrazowo opisuje to Ambroży 22 . Auksencjusz unika osądu wiernych ortodoksyjnych i wybiera jako sędziów przypadkowych ludzi spośród pogan, którzy mają osądzić sprawy wiary ${ }^{23}$. Postawa Merkuryna/Auksencjusza ukazuje przewrotność postępowania heretyków. Oczywiście jest to tylko jeden przypadek, który znamy z pontyfikatu Ambrożego, jednak używane przez niego określenia charakterystyczne są dla Ambrozjańskiego opisu herezji i heretyków. Podobnie wypowiada się w sprawie biskupa Ursyna, który był rywalem papieża Damazego przy wyborze na urząd biskupa Rzymu, a gdy przegrał wzniecił wraz ze swymi zwolennikami rozruchy i zamieszki. Według Ambrożego przystał on do arian i „usiłował niepokoić Kościół mediolański przez godne potępienia zgromadzenia: raz przed bramą synagogi, to znów po domach arian, knując tajemne plany i zbierając swoich zwolenników, a ponieważ nie mógł otwarcie występować na ich zgromadzeniach, szkodził, pouczając ich i kształcąc, w jaki sposób mogą zakłócać pokój Kościoła. A z ich wściekłości czerpał nadzieję, że będzie mógł pozyskać dla siebie ich popleczników i stronników"24.

\footnotetext{
${ }^{17}$ Por. Ambrosius, Epistula 75, 13.

${ }^{18}$ Tamże 15*, 12, SAEMO 21, 333: „suppar nouorum Iudaeorum amentia”, BOK 28, 255.

${ }^{19}$ Por. tamże $75 \mathrm{a}, 31$.

${ }^{20}$ Por. tamże 75a, 20.

${ }^{21}$ Tamże 75a, 22, SAEMO 21, 126: „mutauit sibi uocabulum [...] ad decipiendam plebem”,

${ }^{22}$ Por. tamże.

${ }^{23}$ Por. tamże 75a, 26.

${ }^{24}$ Tamże 5*, 3, SAEMO 21, 156: „turbare Mediolanensem ecclesiam coetu detestabili moliebatur cum Valente, nunc ante synagoga fores, nunc in Arrianorum domibus miscens occulta consilia et suos iungens, et, quoniam ipse aperte in eorum congregationes prodire non poterat, instruens et informans quemadmodum pax ecclesiae turabretur; quorum furore respirabat quod eorum posset fautores et socios emereri”, BOK 28, 156-157.
} BOK $28,87$. 
Ostatecznie określa go Ambroży jako niemającego honoru biskupa, dalekiego od wszelkiego poczucia wstydu, siejącego zamieszanie i próbującego podburzać pogan i ludzi nikczemnych ${ }^{25}$. Miał on przystapić do arian, niepokoić Kościół mediolański i pouczać innych jak zakłócać pokój Kościoła ${ }^{26}$, a ostatecznie domaga się posłuchania u władców ${ }^{27}$. Synod przedstawiając sprawę imperatorom ostrzega ich, czyni to jednak w sposób wyjątkowo łagodny, pełen bólu, ale jednocześnie z utraconą nadzieją na pojednanie:

„Bo wstyd [o tym] mówić, niestosownym jest opowiadać, jak haniebnym zarzutem ugodzili w jego dobrą sławę [współobywatele Ursyna - MW]. Przynajmniej tą hańbą powstrzymany, powinien był milczeć; a gdyby miał jakieś poczucie honoru biskupa, pokój i zgodę Kościoła przedłożyłby nad swoje ambicje i dążenie. Jednakże on, daleki od wszelkiego poczucia wstydu, posławszy list przez kastrata Paschazjusza - chorążego jego szaleństwa - sieje zamieszanie i próbuje podburzać także pogan i [ludzi] nikczemnych"28.

W innych listach Ambroży ukazuje podobne działania heretyków, którzy wzniecają prześladowania przeciwko katolikom ${ }^{29}$, co więcej nie mają oni odwagi pokazać się publicznie, gdyż wielu z nich jest obcokrajowcami i prowadzą nieustabilizowane życie ${ }^{30}$. Jak można zauważyć $\mathrm{z}$ tych przykładów Ambroży negatywnie prezentuje i ocenia postępowanie heretyków, nie boi używać się w korespondencji - również tej oficjalnej skierowanej do cesarzy - słów ostrych i jednoznacznie określających i potępiających heretyków.

2. Postępowanie z heretykami - walka o jedność Kościoła. Ambroży nie poprzestaje w swoich listach na ukazaniu istoty i działania heretyków, ale również proponuje działania wobec nich. Przede wszystkim daje swoistą receptę samym heretykom. W liście 36. pisze tak:

„Niech się nie zbliżają do wiernych, niech nie rozszerza się cudzołożne nasienie. Niech rozważa, co im się przydarzyło z powodu ich wiarołomstwa, niech żyją w spokoju, aby szli za prawdziwą wiarą"31.

${ }^{25}$ Por. tamże $5^{*}, 5$.

${ }^{26}$ Por. tamże $5^{*}, 3$.

${ }^{27}$ Por. tamże $5^{*}, 4$.

${ }^{28}$ Tamże 5*, 5, SAEMO 21, 198: „Pudet enim dicere, inuerecundum est recensere, quam turpi famam eius conuicio sauciauerint; quo saltem pudore perstrictus conticescere debuisset, et si haberet aliquam conscientiam sacerdotis, pacem, ecclesiae concordiamque ambitioni suae et studio preoptaret. Verum longe alienus ab omni uerecundia per abscissum hominem Paschasium signiferum furoris sui missis litteris serit turbas, gentiles quoque et perditos concitare conatur", BOK 28, 157.

${ }^{29}$ Por. tamże $6^{*}, 1$.

${ }^{30}$ Por. tamże 76,12 .

${ }^{31}$ Tamże 36, 28, SAEMO 20, ed. G. Banterle, Milano - Roma 1988, 38: „non appropinquent fidelibus, non serpant adulterina semina; aduertant quid propter suam perfidiam acciderit sibi, quiescant ut ueram fidem sequantur", tłum. P. Nowak: Św. Ambroży z Mediolanu, Listy (36-69), t. 2, BOK 22, Kraków 2003, 18. 
Jednak zauważa jednocześnie, że „umysły nasycone jadem niewiary niełatwo zdołają usunąć klej swej bezbożności" ${ }^{32}$, stąd konieczne jest współdziałanie Kościoła i państwa. Sami heretycy nie są w stanie powrócić na drogę ortodoksji.

Ambroży traktuje zmaganie $\mathrm{z}$ herezjami przede wszystkim w kategoriach walki o pokój i jedność Kościoła i państwa. Była ona wyrazem pragmatycznych zabiegów o zachowanie jedności i pokoju w Kościele, zarówno w sensie węższym, tj. w Mediolanie, jak i w sensie uniwersalnym, a przynajmniej w całym Imperium zachodnim. I w tej optyce trzeba patrzeć na kwestie herezji i heretyków w listach św. Ambrożego ${ }^{33}$. A wtedy nie dziwi, że sprawy herezji poruszane są przede wszystkim w listach do cesarzy lub jako owoc obrad synodów biskupów oraz że mówiąc o herezjach wyraża on wielokrotnie radość z zapanowania pokoju i jedności oraz niepokój z coraz bardziej widocznego podziału na Kościół Wschodu i Zachodu, ale także rozszerzania się doktryn heterodoksyjnych. Tak postępuje na przykład w liście do Teofila, biskupa Aleksandrii, poruszając kwestię schizmy antiocheńskiej ${ }^{34}$. Wobec działań biskupa Teofila i synodu biskupów w Kapui z 391 roku, Mediolańczyk stwierdza:

„Gdy przeto my mieliśmy nadzieję, że za pomocą tych jak najbardziej słusznych postanowień Synodu zostało znalezione lekarstwo i położony kres niezgodzie, twoja świątobliwość pisze, że nasz brat Flawian znowu uciekł się do pomocy próśb i do pośrednictwa rozporządzeń cesarskich. Na próżno więc został włożony wysiłek tylu biskupów"35.

Ambroży wydaje się więc wątpić w owocność podejmowanych działań przeciwko heretykom, mających na celu jedność wiary i pokój Kościoła. Pomimo to jednak nieustannie w swych listach zachęca do walki o nie.

W tej walce zaś pierwszorzędne znaczenie ma według niego znajomość ortodoksyjnej wiary, która ukazywana jest $\mathrm{w}$ wyznaniach wiary (symbolum fidei). W liście 32. do Sabina, który jest jednym z pierwszych czytelników dzieł Ambrożego, ich recenzentem i korektorem, Biskup zachęca go do badania jego dzieł w oparciu o wyznanie wiary, którym

,jest przekonanie, które przeciwko arianom i sabelianom, tak przekazane nam przez ojców zachowujemy, że czcimy Boga Ojca i Jego jednorodzonego Syna

i Ducha Świętego: ta Trójca ma jedną naturę, majestat i bóstwo; w to imię

Ojca i Syna i Ducha Świętego chrzcimy, jak jest napisane. Wierzymy przeto,

32 Tamże 36, 28, SAEMO 20, 38: „difficile quidem imbuti animi infidelitatis uenenis abolere possunt impietatis suae gluttinum”, BOK 22, 18.

${ }^{33}$ Por. K. Ilski, Idea jedności politycznej, społecznej i religijnej w świetle pism Ambrożego z Mediolanu, Poznań 2001, 307.

${ }^{34}$ Por. Ambrosius, Epistula 70.

${ }^{35}$ Tamże 70, 3, SAEMO 21, 30-31: „Cum ex his igitur aequissimis synodi constitutis speraremus iam remedium datum finem que allatum discordiae, scribit sanctitas tua iterum fratrem nostrum Flavianum ad precum auxilia et imperialium rescriptorum suffragia remeavisse. Frustrat ergo tantorum sacerdotum fusus labor", BOK 28, 14. 
że Syn, współwieczny z Ojcem, przyjął ciało, «narodził się z Ducha Świętego i Dziewicy Maryi», jest «równy Ojcu według bóstwa», «w postaci Bożej» (Flp 2, 6), to jest w całej pełni bóstwa, które w Nim mieszka - jak powiedział Apostoł - na sposób ciała (por. Kol 2, 9), ponieważ, jako człowiek, przyjął On postać Sługi i uniżył się aż do śmierci (por. Flp 2, 7.8)"’36.

Powyższa Ambrozjańska reguła wiary jest, jak sam wskazuje, na wskroś antyariańska i antysabeliańska, ale tylko znajomość zawartych w niej najważniejszych prawd wiary pozwoli zaprowadzić jedność. W liście do papieża Syracjusza, Ambroży i inni biskupi zebrani na synodzie w Mediolanie w 393 roku, wobec problemów doktrynalnych dotyczących małżeństwa i dziewictwa Maryi, Matki Jezusa, nawiązują do innego wyznania wiary, którego mają się trzymać wierzący, aby nie ulec lub skorygować błędy herezji:

„niech uwierzą apostolskiemu wyznaniu wiary, którego Kościół rzymski strzeże i zachowuje je zawsze nienaruszone" 37 .

Jeżeli chodzi o generalne zasady dotyczące postępowania $\mathrm{z}$ herezjami i heretykami to wobec różnych poglądów i skomplikowanych podziałów doktrynalnych wśród samych heretyków Ambroży zaleca przede wszystkim ostrożnośćc ${ }^{38}$. Powinna ona przejawiać się nie tylko w rozróżnianiu błędów doktrynalnych, ale także w kontaktach z heretykami. Podstawą jest myślenie wolne od wątpliwości dotyczących wiary, które pozwala uchronić od błędu W mówieniu o sprawach wiary prawdziwej ${ }^{39}$. Temu powinny towarzyszyć oczywiście przede wszystkim w kontaktach z arianami, którzy negują bóstwo Syna Bożego - uwielbienia Chrystusa, które są wyrzutem dla wiarołomców, w których, jak obrazowo pisze Ambroży, znajdują śmierć, w których karcone jest również ich szaleństwo ${ }^{40}$. Ważnym elementem $\mathrm{w}$ walce $\mathrm{z}$ herezjami według Ambrożego jest także kult męczenników ${ }^{41}$, którzy są zawsze świadkami prawdziwej wiary, bo - jak pisze w liście opisującym odnalezienie relikwii

${ }^{36}$ Tamże 32, 4, SAEMO 19, ed. G. Banterle, Milano - Roma 1988, 312: „Professio autem fidei sententia est, quam aduersum Sabellianos et Arrianos ita a maioribus traditam tenemus, ut patrem deum et filium eius unigenitum et spiritum sanctum ueneremur; hanc trinitatem unius esse substantiae, maiestatis, diuinitatis; in hoc nomine patris et fili et spiritus sancti baptizare nos, quemadmodum scriptum est. Filium itaque coaeternum patri suscepisse carnem, «natum de spiritus sancto et uirgine Maria», «aequalem patri secundum diuinitatem» «in dei forma» id est in omni plenitudine diuinitatis quae in illo habitat, ut dixit apostolus, corporaliter, quiz in persona hominis formam serui accepit et se humiliauit usque ad mortem", tłum. P. Nowak: Ambroży z Mediolanu, Listy, t. 1, BOK 9, Kraków 1997, 239-240.

37 Tamże 15*, 5, SAEMO 21, 328: „credatur symbolo apostolorum, quod ecclesia Romana intemeratum semper custodit et seruat”, BOK 28, 253.

${ }^{38}$ Por. tamże 32, 5.

${ }^{39}$ Por. tamże 32, 6.

${ }^{40}$ Por. tamże $75 \mathrm{a}, 19$.

${ }^{41}$ O kulcie relikwii u Ambrożego zob. R. Andrzejewski, Kult relikwii wedtug św. Ambrożego, RTK 26 (1979) z. 4, 73-78. 
Protazego i Gerwazego - oni „mieli tę wiarę, której oni sami [id est - arianie] nie mają: tę wiarę, potwierdzoną przez tradycję przodków"42. W walce o jedność Kościoła i czystość wiary Ambroży dostrzega działanie Boga, który daje ludowi szczególne znaki i wyjątkowych wspomożycieli. Według Biskupa są nimi właśnie męczennicy i dlatego odnalezienie ciał świętych Protazego i Gerwazego widzi jako pomoc od Pana, któremu w przytoczonej w liście homilii dziękuje, że wzbudził dla Kościoła mediolańskiego „tak potężne duchy świętych męczenników w tym czasie, w którym Twój Kościół potrzebuje większej obrony" "33. W liście do Kościoła w Vercelli, w którym przedłużał się wybór nowego biskupa na skutek walk różnych stronnictw, na zakończenie listu - choć $\mathrm{w}$ nim mało miejsca poświęca herezjom i heretykom - przesyła gminie życzenia, aby trwali przy ortodoksyjnej nauce: „Co najważniejsze, nawróćcie się do Pana Jezusa. Niech będzie w was [...] trzeźwość wiernej nauki bez oparów herezji" 4 .

Według Ambrożego konieczna jest też pobożność, ponieważ heretycy

„nie mogą znieść waszej pobożności, gardzą przyczyną tej pobożności i dochodzą aż do tak wielkiego szaleństwa, że negują zasługi męczenników, których dzieła wyznają nawet demony"45.

Oczywiście przede wszystkim konieczna jest znajomość prawowiernej doktryny, którą przedstawia Ambroży w swych dziełach dogmatycznych, które na przykład przesyła cesarzowi Gracjanowi, i o które on sam prosił biskupa Mediolanu ${ }^{46}$.

W takim zmaganiu $\mathrm{z}$ herezjami i heretykami to biskupi są pierwszymi odpowiedzialnymi za tę walkę. W praktyce duszpasterskiej Ambrożego i przełożeństwie nad prowincją kościelną Biskup Mediolanu, jak wynika to z epistolografii, wielokrotnie ukazywał taką rolę biskupów, nade wszystko zgromadzonych na synodach, we współpracy $\mathrm{z}$ cesarzami ${ }^{47}$. To jeden $\mathrm{z}$ takich synodów, z 381 roku w Akwilei, zwracał się do cesarzy Gracjana, Walentyniana i Teodozjusza, w obronie ortodoksyjnej wiary, ,,aby wiarołomstwo arian nie mogło

${ }^{42}$ Ambrosius, Epistula 77, 20, SAEMO 21, 164-166: „fidem in his fuisse eam quam isti non habent iudicarent, fidem illam maiorum traditione firmatam”, BOK 28, 116.

${ }^{43}$ Tamże 77, 10, SAEMO 21, 160: ,quo hoc tempore tales nobis sanctorum martyrum spiritus excitasti, quo ecclesia tua praesidia maiora desiderat”, BOK $28,112$.

${ }^{44}$ Tamże 14*, 113, SAEMO 21, 320: „Ad summam conuertimini omnes ad dominum Iesum. Sit in vobis [...] sobrietas doctrinae fidelis sine haeresis temulentia", BOK 28, 247.

${ }^{45}$ Tamże 77, 16, SAEMO 21, 162: „Cui tamen celebritati uestrae qui solent inuident et quia celebritatem uestram inuidis animis ferre non possunt causam celebritatis oderunt atque in tantum amentiae prodeunt ut negent martyrum merita, quorum opera etiam daemones confitentur", BOK 28, 114.

${ }^{46}$ Por. tamże 12*, 4-7; tenże, De fide I 3.

${ }^{47}$ Ogólnie o biskupach i ich roli w listach Ambrożego zob. M. Zelzer, Vescovi e pastori alla luce delle lettere ambrosiane, w: Vescovi e pastori in epoca teodosiana, II, SEA 58, Roma 1997, 559-568. 
już dłużej ani się ukrywać, ani po cichu rozszerzać" ${ }^{48}$. Dawali oni władcom następujące rady $\mathrm{w}$ postępowaniu $\mathrm{z}$ heretykami: należy ich upomnieć, a po upomnieniu unikać, ,nie należy ich pozdrawiać ani spotykać się z nimi”"49. A w konkretnym przypadku heretyka Ursyna zwracali się do cesarzy prosząc, aby nie pozwolili mu niepokoić Kościoła Rzymskiego, „głowy całego rzymskiego świata, i tej najświętszej apostolskiej wiary: stąd bowiem rozlewają się na wszystkie [Kościoły] prawa ich czcigodnej komunii" ${ }^{50}$. Ze względu na to domagali się i prosili, aby władcy odebrali Ursynowi możność podstępnego wyłudzania przychylności cesarskiej ${ }^{51}$. W liście zaś skierowanym do cesarza Teodozjusza po zakończeniu synodu w Akwilei, Ambroży wraz z innymi biskupami wskazuje, że należy usunąć zagrożenie ze strony tych, którzy usiłują wprowadzać do Kościoła nauczanie Apolinarego z Laodycei oraz aby mu „dowiedziono [wprowadzenia] nowej nauki i wykazano błąd, tak iż w żaden sposób nie mógłby się ukrywać pod powszechną nazwą wiary" ${ }^{52}$. Ponadto postulowano, że ma się on zrzec urzędu i tytułu biskupa ${ }^{53}$. Warto tu podkreślić, że Ambroży oraz inni biskupi Italii wypowiadają się również w sprawach Kościoła wschodniej części Imperium i trwania jej przy ortodoksji. Biskupi mają zatem za zadanie czuwać nad prawowiernością i wskazywać drogi walki z herezjami. W sposób dosłowny pisze o tym Ambroży oraz biskupi zebrani na synodzie w Mediolanie w 393 r. w liście skierowanym do papieża Syracjusza, wychwalając jego czujność wobec herezji:

„W liście twojej świątobliwości rozpoznaliśmy czujność dobrego pasterza, gdyż pilnie strzeżesz powierzonej ci bramy i z miłosną troską pilnujesz owczarni Chrystusa, godzien tego, by owce Pana cię słuchały i szły za tobą (por. J 10, 2-4). A ponieważ znasz owieczki Chrystusa, przeto łatwo spostrzegasz wilki i, jako przewidujący pasterz, występujesz przeciwko nim, żeby one ukąszeniami swego wiarołomstwa i zwiastującym śmierć wyciem nie rozpraszały Pańskiej owczarni" ${ }^{54}$.

${ }^{48}$ Ambrosius, Epistula 5*, 1, SAEMO 21, 194: „ne Arrianorum perfidia ulterius possit uel latere uel serpere", BOK 28, 155.

49 Tamże 5*, 4, SAEMO 21, 198: „dixerit declinandas huiuscemodi bestias nec salutatione recipiendas atque congressu”, BOK 28, 157.

${ }^{50}$ Tamże: ,totius orbis Romani caput Romanam ecclesiam atque illam sacrosantam fidem apostolorum ne turbari sineret obsecranda fuit clementia uestra; inde enim in omnes uenerandae communionis iura dimanant”, BOK 28, 157.

${ }^{51}$ Por. tamże.

${ }^{52}$ Tamże 8*, 4, SAEMO 21, 216: „,conuictus in dogmate nouo et redergutus in errore nequaquam sub generali fidei lateret nomine", BOK 28, 171.

${ }^{53}$ Por. tamże.

${ }^{54}$ Tamże 15*, 1, SAEMO 21, 326: „Recognouimus litteris sanctitatis tuae boni pastoris excubias, qui diligenter commissam tibi ianuam serues et pia sollicitudine Christi ouile custodias, dignus quem oues domini audiant et sequantur. Et ideo quia nosti ouiculas Christi, lupos facile deprehendis et occurris quasi prouidus pastor, ne isti morsibus perfidiae suae feralique ululatu dominicum ouile dispergant”, BOK 28, 251. 
Biskup powinien być więc wobec herezji czujny, strzegący powierzonej mu owczarni, przewidujący i dostrzegający zagrożenia za strony herezji i podejmujący walkę i działania w celu zapobieżenia dalszego rozwoju błędnej nauki.

Jednak nie tylko działanie wspólne biskupów ma znaczenie w walce $\mathrm{z}$ herezjami, równie ważna jest postawa każdego pojedynczego pasterza. Przykładem na to jest opór biskupa Ambrożego w sporze o bazyliki. Spór ten to nie tylko kwestia budynku, ale przede wszystkim ortodoksyjnej wiary i wierności jej. Wyraźnie o takich motywach walki z herezją mówi Mediolańczyk w liście 75a. będącym zapisem kazania Biskupa wygłoszonego w Niedzielę Palmową w 386 r.:

„W czym więc odpowiedziałem hardo? Powiedziałem bowiem na spotkaniu: «Niech mnie Bóg broni, abym oddał dziedzictwo Chrystusa». Jeśli on nie oddał dziedzictwa swych przodków, czy ja oddam dziedzictwo Chrystusa? Lecz dodałem także: «Niech mnie Bóg broni, abym oddal dziedzictwo przodków: to jest dziedzictwo Dionizego, który z powodu wiary zmarł na wygnaniu, dziedzictwo wyznawcy Eustorgiusza, dziedzictwo Miroklesa i wszystkich poprzednich wiernych biskupów». Ja odpowiedziałem to, co należy do biskupa; cesarz niech robi to, co należy do cesarza. Prędzej zdoła mi odebrać życie niż wiarę"55.

Wyraźny jest element chronienia i walki o dziedzictwo ortodoksyjnej wiary. Ważne jest to, że słowa te zawarte są w homilii, która ma być z definicji pouczeniem, ukazaniem wzoru i sposobu postępowania, $w$ tym przypadku $\mathrm{z}$ heretykami. Wiara ortodoksyjna, której należy bronić, była bowiem broniona i zachowana przez tak wielu jego poprzedników na mediolańskiej stolicy biskupiej. Również on, a za jego przykładem wszyscy kapłani i wierni, powinni więc raczej być gotowi oddać życie za ortodoksyjną wiarę niż ją utracić i dlatego w liście 75. pisał do cesarza Walentyniana: ,idę za wyjaśnieniem Soboru Nicejskiego, od którego ani śmierć, ani miecz nie zdoła mnie odłączyć" 56 .

Niestety nie zawsze biskupi potrafili w ten sposób bronić ortodoksyjnej wiary, jak widać to było na podanych tu już przykładach, wielu z nich oddało dziedzictwo ortodoksji i przeszło na stronę heretyków. Niektórzy z nich, jak opisuje to Ambroży w liście 75. poświęconym również sprawie bazylik, za rządów cesarza Konstancjusza,

„najpierw podpisali formułę prawdziwej wiary, lecz ponieważ niektórzy chcieli sądzić o sprawach wiary w cesarskim pałacu, swymi oszustwami doprowadzili do tego, że te postanowienia biskupów zostały zmienione. Oni jednak zaraz

${ }^{55}$ Tamże 75a, 18, SAEMO 21, 124: „Quid igitur a me responsum est contumaciter? Dixi enim conuentus: «Absit a me ut tradam Christi hereditatem». Si ille patrum hereditatem non tradidit, ego tradam Christi hereditatem? Sed et hoc addidi: «Absit ut tradam hereditatem patrum hoc est hereditatem Dionysii qui in exilio in causa fidei defunctus est, hereditatem Eustorgii confessoris, hereditatem Mirocletis atque omnium retro fidelium episcoporum». Respondi ego quod sacerdotis est: quod imperatoris est faciat imperator. Prius est ut animam mihi quam fidem auferat", BOK 28, 85.

${ }^{56}$ Tamże 75, 14, SAEMO 21, 112: „,sequens tractatum concilii Nicaeni, a quo me nec mors nec gladius poterit separare", BOK 28, 75 . 
odwołali tę niewłaściwą decyzję i z pewnością w Rimini większość biskupów potwierdziła wiarę Soboru Nicejskiego i potępiła dekrety ariańskie"s7.

Ambroży ukazuje więc negatywne postępowanie niektórych biskupów i osób, które podstępem doprowadziły do zanegowania ortodoksyjnej wiary, ale jednocześnie podkreśla wierność pozostałych uchwałom Soboru Nicejskiego i ukazuje możliwość powrotu do prawdziwej reguły wiary i odrzucenia herezji.

Inną grupa, która winna być zaangażowana w obronę ortodoksyjnej doktryny są oczywiście imperatorzy ${ }^{58}$. Przykładem władców działających na rzecz wiary ortodoksyjnej byli dla Ambrożego cesarz Teodozjusz, który przywrócił katolikom ich kościoły i wypędził heretyków ${ }^{59}$ oraz cesarz Gracjan, który przywrócił pokój Kościoła oraz zamknął usta i serca ludzi przewrotnych ${ }^{60}$. Dzięki ich działaniu

„we wszystkich okolicach i regionach, od kresów Tracji aż do oceanu, komunia wiernych pozostaje jedna i nieskażona we wschodnich częściach [cesarstwa] [...] - po wyrzuceniu arian, którzy przemocą przywłaszczyli sobie kościoły święte świątynie Boże są nawiedzane przez samych tylko katolików"61.

$\mathrm{Z}$ pewnością jest $\mathrm{w}$ tym nieco retorycznej przesady oraz $\mathrm{w}$ pewien sposób naturalnego captatio benevolentiae biskupów wobec trzech imperatorów. Jest z pewnością także zachęta do dalszego działania na rzecz jedności, pokoju i ortodoksyjnej wiary. Wydaje się, że jednak z biegiem lat list ten odszedł w zapomnienie. Napisany został bowiem w 381 roku na wiele lat przed wydarzeniami, które będą miały miejsce w 386 roku podczas wspominanego tu już wielokrotnie sporu o bazyliki, którego spiritus movens będzie jeden z adresatów listu biskupów - cesarz Walentynian. Ambroży w sporze tym wskazywał jasno rolę cesarza - ma być wierny ortodoksji. Jeżeli opowiada się zaś po

${ }^{57}$ Tamże 75, 15, SAEMO 21, 112: ,sinceram primo scripserant fidem, sed dum uolunt quidam de fide intra palatium iudicare, id egerunt ut circumscriptionibus illa episcoporum iudicia mutarentur. Qui tamen inflexam statim reuocauere sententiam et certe maior numerus Arimini Nicaeni concilii fidem probauit, Arriana decreta damnauit", BOK 28, 76.

${ }^{58}$ Por. M. Sordi, I rapporti di Ambrogio con gli imperatori del suo tempo, w: Nec timeo morti. Atti del Congresso internazionale di studi Ambrosiani nel XVI centenario della morte di sant'Ambrogio, ed. L.F. Pizzolato - M. Rizzi, Milano 1998, 107-118; K. Gross-Albenhausen, „Imperator christianissimus": der christliche Kaiser bei Ambrosius und Johannes Chrysostomus, Stuttgart 1999.

${ }^{59}$ Por. Ambrosius, Epistula 9*, 1.

${ }^{60}$ Por. tamże 12*, 2. Na temat szczególnej relacji Ambroży - Gracjan zob. J.-R. Palanque, Un épisode des rapports entre Gratien et saint Ambroise. À propos de la lettre I de saint Ambroise, REA 30 (1928) 291-301; G. Gottlieb, Ambrosius von Mailand und Kaiser Gratian, Hypomnemata. Untersuchungen zur Antike und zu ihrem Nachleben 40, Göttingen 1973; T.D. Barnes, Ambrose and Gratian, „Antiquité Tardive” 7 (1999) 165-174.

${ }^{61}$ Ambrosius, Epistula 6*, 3, SAEMO 21, 202: „Per omnes autem tractus atque regionem a Thracorum claustris usque ad Oceanum manet intemerata fidelium atque una communio. In orientalibus autem partibus [...] eiectis Arrianis, qui ecclesias uiolenter inuaserant, sacra dei templa per solos catholicos frequentari”, BOK 28, 160-161. Por. tamże 6*, 1 . 
stronie heretyków, to jego miejsce jest poza Kościołem. Ambroży bowiem, w obliczu sporu z arianami, wyraźnie zaostrza swój punkt widzenia na udział imperatora $\mathrm{w}$ kwestiach wiary. We wspomnianym powyżej fragmencie listu 75a, wyraźnie wskazywał, że biskup ma robić, co należy do biskupa, a cesarz, co do cesarza, wskazując, że ma się on nie angażować w sprawy Kościoła ${ }^{62}$. Wyraźnie mówi o tym we wcześniejszym fragmencie listu:

„Któż zaprzeczy, iż sprawę wiary należy rozpatrywać w kościele? Jeśli ktoś ma zaufanie, niech przyjdzie tutaj: albo sąd cesarza jest już przychylny [dla przeciwnej strony] - gdyż przez dane prawo jasno pokazał, że zwalcza naszą wiarę - albo nie powinien starać się spełniać oczekiwanych dążeń niektórych intrygantów. Nie dopuszczę, aby ktoś kupczył zniewagą wyrządzaną Chrystusowi" ${ }^{63}$.

Ambroży wymaga zatem od imperatora jasnego opowiedzenia się po stronie ortodoksyjnej i zaprzestania wydawania praw, które są przeciwko prawdziwej wierze.

Nie ulega wątpliwości, że sprawa walki o czystość doktryny i o jedność i pokój w Kościele były głównymi punktami biskupiej posługi Ambrożego z Mediolanu. Wielokrotnie w swojej korespondencji wyrażał troskę o ortodoksyjną wiarę, o przywrócenie jedności i pokoju. $Z$ pewnością była $\mathrm{w}$ nim wola świętej walki o te wartości, ale jednocześnie nadzieja na pokojowy powrót heretyków na łono ortodoksji. Lektura listów św. Ambrożego nie pozostawia jednak złudzeń - Biskup Mediolanu tracił stopniowo nadzieję na takie zakończenie przede wszystkim ariańskich sporów. Powody do takiej postawy wielokrotnie przedstawia w swych listach - spór o bazyliki, postawy heretyków, słabość ortodoksyjnych wiernych i kapłanów. Wydaje się jednak, że pomimo wszystko wciąż tli się w nim iskra nadziei, dlatego do ostatniej litery zachowanych listów wzywa do powrotu na łono Kościoła i ortodoksji.

${ }^{62}$ Por. Ambrosius, Epistula 75a, 18.

${ }^{63}$ Tamże 75a, 3, SAEMO 21, 116: „Causa fidei in ecclesia agendam quis abnuat? Si quis confidit huc veniat; inclinatum iam uel imperatoris iudicium, quod lata lege patefecit, quod impugnat fidem, uel sperata ambientium quorundam studia non requirat. Non committo ut quisquam uendat iniuriam Christi”, BOK 28, 79. 


\section{HOPE FOR THE UNITY? \\ HERESIES AND HERETICS IN ST. AMBROSE'S LETTERS}

\section{(Summary)}

This article presents the results of the analysis of the correspondence of St. Ambrose, the Bishop of Milan, concerning heresies and heretics and the hope of their final reconciliation with the Church. The article consists of two essential parts, the first shows the definition and essence of heresies and heretics, including examples of heretics and how they act. The second part focuses on dealing with heretics and fighting for the unity of the Church. This section shows the ways in which this fight is taking place and the parties responsible for it: the bishops and the emperors. Reading the letters of St. Ambrose does not leave any illusions - the Bishop of Milan has gradually been losing the hope for ending such conflicts, above all with the Arians. Reasons for such an attitude are repeatedly presented in his letters - the conflict of the basilicas, the attitudes of the heretics, the weakness of orthodox believers and priests. It seems, however, that in spite of everything still smoulders in him spark of hope, because to the last letter of preserved correspondence he calls for return to the bosom of the Church and orthodoxy.

Key words: Ambrose of Milan, heresy, heretics, letters, unity, hope.

Słowa kluczowe: Ambroży z Mediolanu, herezja, heretycy, listy, jedność, nadzieja.

\section{BIBLIOGRAFIA}

\section{Źródła}

Ambrosius Mediolanensis, Epistulae, SAEMO 19-21, ed. G. Banterle, Milano - Roma 1988, tłum. P. Nowak: Ambroży z Mediolanu, Listy, t. 1, BOK 9, Kraków 1997, t. 2 , BOK 22, Kraków 2003, t. 3, BOK 28, Kraków 2012.

\section{Opracowania}

AndRZEJewsKi R., Kult relikwii wedtug św. Ambrożego, RTK 26 (1979) z. 4, 73-78.

Barnes T.D., Ambrose and Gratian, „Antiquité Tardive” 7 (1999) 165-174.

BARNES T.D., Ambrose and the Basilicas of Milan in 385 and 386: The primary documents and their implications, ZACh 4 (2000) 282-299.

BARTH F., Ambrosius und die Synagoge von Callinicum, ,Theologische Zeitschrift aus der Schweiz" b.d. (1889) 65-86.

Colish M., Why the Portiana?: Reflections on the Milanese Basilica Crisis of 386, JECS 10 (2002) 361-372.

Cracco Ruggini L., Ambrogio a le opposizioni anticattoliche fra il 383 e il 390, „Augustinianum" 14 (1974) 409-449.

Duval Y.M., Ambroise, de son élection à sa consécration, w: Ambrosius Episcopus. Atti del Congresso internazionale di studi ambrosiani nel XVI centenario della elevazione 
di sant'Ambrogio alla cattedra episcopale, ed. G. Lazzati, Studia Patristica Mediolanensia 6, Milano 1976, 243-283.

Gotтlieb G., Ambrosius von Mailand und Kaiser Gratian, Hypomnemata. Untersuchungen zur Antike und zu ihrem Nachleben 40, Göttingen 1973.

Gross-Albenhausen K., ,Imperator christianissimus”: der christliche Kaiser bei Ambrosius und Johannes Chrysostomus, Stuttgart 1999.

Grzywaczewski J., Appointing Bishops in the First Centuries, Lublin 2013.

ILski K., Idea jedności politycznej, społecznej i religijnej w świetle pism Ambrożego z Mediolanu, Poznań 2001.

Labriolle P. DE, Saint Ambroise et l'affaire de Callinicum, „Revue des Cours et Conférences" 16 (1898) 78-96.

Nauroy G., Ambroise et la question juive à Milan à la fin du IV siècle. Une nouvelle lecture de l'Epistula 74 (Maur. 40) à Théodose, w: Les chrétiens et leurs adversaires dans l'Occident latin au IV siècle, ed. J.-M. Poinsotte, Rouen 2001, 37-59.

NAUroy G., Le fouet et le miel. Le combat d'Ambroise en 386 contre l'arianisme milanaise, RechAug 23 (1988) 3-86.

Palanque J.-R., Un épisode des rapports entre Gratien et saint Ambroise. À propos de la lettre I de saint Ambroise, REA 30 (1928) 291-301.

PAŁUCKI J., Św. Ambroży, opatrznościowy maż Kościoła - między starymi a nowymi czasy, w: Bóg Ojciec i przełom wieków w myśli patrystycznej, red. I. Salamonowicz-Górska - J. Naumowicz - S. Strękowski, Warszawa 2001 = SACh 15 (2001) 196-207.

PAŁUCKi J., Święty Ambroży jako duszpasterz w świetle ekshortacji pastoralnych, Lublin 1996.

Simonetti M., Aussenzio di Milano, DPAC I 449-450.

Sordi M., I rapporti di Ambrogio con gli imperatori del suo tempo, w: Nec timeo morti. Atti del Congresso internazionale di studi Ambrosiani nel XVI centenario della morte di sant'Ambrogio, ed. L.F. Pizzolato - M. Rizzi, Milano 1998, 107-118.

ZELzer M., Vescovi e pastori alla luce delle lettere ambrosiane, w: Vescovi e pastori in epoca teodosiana, II, SEA 58, Roma 1997, 559-568. 